Article

\title{
Partition and Fate of Phthalate Acid Esters (PAEs) in a Full-Scale Horizontal Subsurface Flow Constructed Wetland Treating Polluted River Water
}

\author{
Lei Zheng ${ }^{1}$, Tingting Liu ${ }^{1}$, En Xie ${ }^{2}$, Mingxue Liu ${ }^{1}$, Aizhong Ding ${ }^{1}$, Bo-Tao Zhang ${ }^{1}$, \\ Xiaoyan $\mathrm{Li}^{1, *}$ and Dayi Zhang ${ }^{3, *}$ \\ 1 College of Water Sciences, Beijing Normal University, Beijing 100875, China; zhengleilei@bnu.edu.cn (L.Z.); \\ tingty@mail.bnu.edu.cn (T.L.); 201221470023@mail.bnu.edu.cn (M.L.); ading@bnu.edu.cn (A.D.); \\ zhangbotao@bnu.edu.cn (B.-T.Z.) \\ 2 College of Water Resources and Civil Engineering, China Agricultural University, Beijing 100083, China; \\ xe@cau.edu.cn \\ 3 School of Environment, Tsinghua University, Beijing 100084, China \\ * Correspondence: lxynmu.2008@163.com (X.L.); zhangdayi@tsinghua.org.cn (D.Z.)
}

Received: 18 February 2020; Accepted: 16 March 2020; Published: 19 March 2020

check for updates

\begin{abstract}
When used as highly produced chemicals and widely used plasticizers, Phthalate acid esters (PAEs) have potential risks to human life and the environment. In this study, to assess the distribution and fate of PAEs, specifically inside a full-scale horizontal subsurface flow constructed wetland, four PAEs including dimethyl phthalate (DMP), diethyl phthalate (DEP), di- $n$-butyl phthalate (DBP), and bis (2-ethylhexyl) phthalate (DEHP) were investigated. In effluent, PAEs concentration decreased 19.32\% (DMP), 19.18\% (DEP), 19.40\% (DBP), and 48.56\% (DEHP), respectively. Within the wetland, PAEs partitioned in water $(0.18-1.12 \mu \mathrm{g} / \mathrm{L}, 35.38-64.92 \%)$, soil $(0.44-5.08 \mu \mathrm{g} / \mathrm{g}, 1.02-31.33 \%)$, plant $(0.68-48.6 \mu \mathrm{g} / \mathrm{g}, 0.85-36.54 \%)$, air and biological transformation $(2.72-33.21 \%)$. The results indicated that soil and plant adsorption contributed to the majority of PAE removal, digesting DMP (19.32\%), DEP (19.18\%), DBP (19.40\%), and DEHP (48.56\%) in constructed wetlands. Moreover, the adsorption was affected by both octanol/water partition coefficient $\left(K_{o w}\right)$ and transpiration stream concentration factors (TSCF). This work, for the first time, revealed the partition and fate of PAEs in constructed wetlands to the best of our knowledge.
\end{abstract}

Keywords: balance; constructed wetlands; full scale; phthalate acid esters

\section{Introduction}

Phthalate acid esters (PAEs) and phthalates are synthetic compounds used mainly as plasticizers to improve the flexibility, durability, and transparency of plastics [1]. As additives in numerous products, including coatings, coverings, insecticides, flooring, drainpipes, packaging, cosmetics, adhesives, and paints [2], they may migrate into the environment via various pathways including microbial transformation, microsomal metabolism, and sunlight exposure [3]. With strong chemical bond to the matrices of polymers, PAEs are persistent and found in almost all the environments, such as rivers [4], sediments [5], soils [6], sewage [7], air [8], biota [9], and even in human tissue [10]. Many pieces of evidence show the carcinogenic, teratogenic, and estrogenic effects of PAEs [11]. Their potential risk to human and animal health has attracted increasing attention around the world. Accordingly, in 1977, six PAEs were listed as priority pollutants by the United States Environmental Protection Agency (US EPA) [12], including dimethyl phthalate (DMP), diethyl phthalate (DEP), di-n-butyl phthalate (DBP), bis (2-ethylhexyl) phthalate (DEHP), di- $n$-octyl phthalate, and butyl benzyl phthalate. DEHP 
was further classified as one of the 33 hazardous substances to be controlled in surface water by the European Community in 2000 [13].

As receptors of PAEs, many rivers and other aquatic ecosystems worldwide have been polluted by PAEs, leading to the importance of finding appropriate treatments to solve the problem. Many techniques have been developed to remove PAEs from water, including activated carbon adsorption [14], chemical advanced-oxidation processes [15], and conventional wastewater treatment plants [16]. Though these treatments are effective in reducing PAEs levels, they suffered from the relatively low cost-effectiveness and treatment capacities for low-level PAEs contamination in the large volumes of water, such as rivers and lakes. Constructed wetlands, therefore, draw increasing attention as a cost-effective bio-filtration system [17]. As an efficient way to mitigate pollutants and improve the water quality of rivers and lakes, constructed wetlands have been applied to remove conventional organic pollutants with satisfactory performance [18]. With more organic micropollutants found in municipal wastewater and remaining stable through the treatment plant, such as pharmaceutical and personal care products, herbicides, estrogens, and androgens [19], there were increasing interests in applying constructed wetlands as an advanced technique to remove their amounts further [20]. More importantly, the mechanisms of such organic micropollutants were still not clear and there was a lack of studies on the micropollutants partition and fate in constructed wetlands.

The partition and fate of PAEs were determined by many factors across multimedia phases [21]. Though some research [22] has investigated PAE removal in wetlands, their partition and fate are not well discussed in these cases. Some multimedia fate models have been developed for hydrophobic organic matters [23], such as polycyclic aromatic hydrocarbons (PAHs) [24], polybrominated diphenyl ethers (PBDEs) [25], and Benzo[a]pyrene [26]. Some environmental factors are found with critical roles in determining the partition of organic matters across multimedia [27], such as octanol/water partition coefficient $\left(K_{o w}\right)$ and transpiration stream concentration factor (TSCF) [28], but only limited research addresses PAEs [29].

In this study, we chose four PAEs (DMP, DEP, DBP, and DEHP) from the US EPA priority list and investigated their total removal efficiency in a full-scale constructed wetland with the horizontal subsurface flow. Their unique partitions and fates in the wetland were further analyzed and discussed within the multimedia system (water, soils, plants, and air). By detecting the concentration and evaluating the enrichment coefficient (the ratio of pollution concentration in plants to soils) [30] in Phragmites australis tissues, the fates of different PAEs behaved differently, and the results helped deepen our understanding on the improvement of constructed wetlands in organic micropollutant removal.

\section{Materials and Methods}

\subsection{Field Site}

This field study was performed in a full-scale constructed wetland with horizontal subsurface flow located in Tianjin, China $\left(39^{\circ} 08^{\prime} \mathrm{N}, 117^{\circ} 12^{\prime} \mathrm{E}\right)$. The annual temperature averages $14^{\circ} \mathrm{C}$, and the monthly means range from $-2{ }^{\circ} \mathrm{C}$ in January to $28^{\circ} \mathrm{C}$ in July. This wetland consisted of 55 chambers in parallel, which is $31 \mathrm{~m}$ in length in the direction of the flow, $20 \mathrm{~m}$ in width, and $0.8 \mathrm{~m}$ in depth. The wetland was planted with Phragmites australis, as shown in Figure 1. Constructed and operated since 2007 to treat polluted river water, the daily treatment capacity of the studied constructed wetland was $170 \mathrm{~m}^{3}$ with $24 \mathrm{~h}$ hydrological retention time (HRT). 


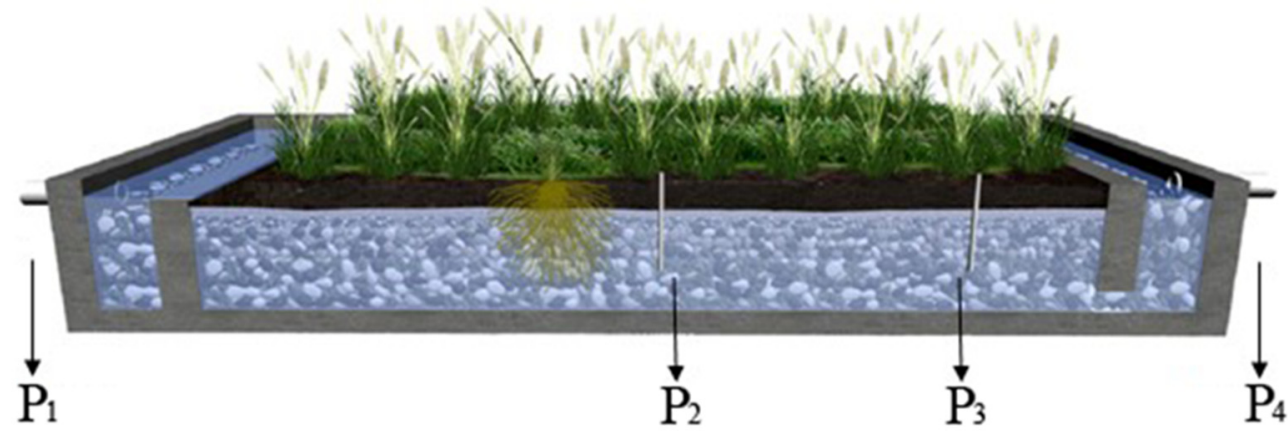

Figure 1. Phragmites australis planting and sampling sites in wetland. Four pipes $\left(\mathbf{P}_{\mathbf{1}}-\mathbf{P}_{\mathbf{4}}\right)$ were used for the collection of samples, where $\mathbf{P}_{\mathbf{1}}$ is the sampling outlet of the influent, $\mathbf{P}_{\mathbf{4}}$ is the sampling outlet of the effluent, $\mathbf{P}_{\mathbf{2}}$ and $\mathbf{P}_{\mathbf{3}}$ are the sampling sites inside the wetland.

\subsection{Sampling}

All the water, soil, and plant samples were collected four times from July to September 2014. For influent $\left(\mathrm{P}_{1}\right.$, Figure 1$)$ and effluent $\left(\mathrm{P}_{4}\right.$, Figure 1$)$ water sampling, the water samples were collected using a stainless-steel bucket. For water sampling inside the wetland $\left(\mathrm{P}_{2}\right.$ and $\mathrm{P}_{3}$, Figure 1$)$, the $70-\mathrm{cm}$-long stainless-steel tubes $(6 \mathrm{~mm}$ in diameter with several small holes at the bottom) were introduced and fixed into the ground, and the water samples were sucked from the tubes via syringe. Soil sample collection was carried out at the same sites as water samples, using a shovel to take the whole top layer soils $(0-20 \mathrm{~cm})$. At each sampling point, 10 Phragmites australis individuals (near the water sampling sites) were collected and divided into leaves, stems, and roots before analysis. Moreover, the sample sites as listed in Figure 1.

All the samples were transferred to the laboratory within six hours. The water samples were stored in $1 \mathrm{~L}$ amber glass bottles with polytetrafluoroethylene caps at $4{ }^{\circ} \mathrm{C}$. Soil samples were stored as bulk samples in amber glass jars with glass caps at $-20^{\circ} \mathrm{C}$. The plant tissues were wrapped in aluminized paper and kept in sealed plastic bags at $4{ }^{\circ} \mathrm{C}$. All samples were extracted within seven days of collection.

\subsection{Sample Pretreatment}

Water samples were pretreated according to US EPA methods 3535 and 8061a, with slight modifications, according to Zheng's research [31]. The $1000 \mathrm{~mL}$ water samples were filtered through the $0.45 \mu \mathrm{m}$ millipore membrane (Millipore, Bedford, MA, USA) and then pre-concentrated by solid-phase extraction (recovery rates reached $93.8 \%$, and pre-concentration 2500 times). Each cartridge (C18, $500 \mathrm{mg}$, $6 \mathrm{~mL}$; Supelco, Bellefonte, PA, USA) was activated by adding $2 \mathrm{~mL}$ methylene chloride, $1 \mathrm{~mL}$ acetone, $2 \mathrm{~mL}$ methanol, and $2 \mathrm{~mL}$ purified water. After sample loading (at $4 \mathrm{~mL} / \mathrm{min}$ ), the cartridge was air-dried for $10 \mathrm{~min}$. Then, $8 \mathrm{~mL}$ of methanol was passed through the cartridge at $1 \mathrm{~mL} / \mathrm{min}$. The effluent was evaporated to dryness under a gentle nitrogen stream. The residue was then re-dissolved with $400 \mu \mathrm{L}$ n-hexane [31].

Plant samples were oven-dried at $60^{\circ} \mathrm{C}$ for $48 \mathrm{~h}$ and then ground using a glass mortar and sieved to pass through a $1 \mathrm{~mm}$ stainless-steel sieve. The $1000 \mathrm{~g}$ plant sample was added into a $100 \mathrm{~mL}$ Erlenmeyer flask with a ground-glass stopper, with additives of $25 \mathrm{~mL}$ methanol and $3 \mathrm{~g}$ anhydrous sodium sulfate. After stored overnight, the flask was shaken at $60 \mathrm{rpm}$ for $4 \mathrm{~h}$. The extract was filtered through a $0.45 \mu \mathrm{m}$ membrane (Millipore, USA). The flasks and plant tissues were rinsed three times with $50 \mathrm{~mL}$ of methanol. The combined filtrate was then evaporated to dryness using a rotary evaporator. The residue was re-dissolved with $400 \mu \mathrm{L}$ n-hexane (recovery rates reached $91.4 \%$ and pre-concentration 62.5 times) [31]. 


\subsection{PAEs Analysis}

PAEs analyses were performed using a 7890-5975 GC-MS (Agilent, USA), operated in the electron-impact and selective-ion-monitoring modes. The column was an HP-5 ms capillary column (30 $\mathrm{m} \times 250 \mu \mathrm{m}$ i.d.; $0.25 \mu \mathrm{m}$ film thickness; Agilent, USA). The temperatures of the injector and ion source were maintained at 280 and $250^{\circ} \mathrm{C}$, respectively. The carrier gas was helium $(1 \mathrm{~mL} / \mathrm{min})$. The GC oven temperature was set at $60^{\circ} \mathrm{C}$ for $1 \mathrm{~min}$, increased from $60^{\circ} \mathrm{C}$ to $220^{\circ} \mathrm{C}$ at $20^{\circ} \mathrm{C} / \mathrm{min}$, held constant at $220^{\circ} \mathrm{C}$ for $1 \mathrm{~min}$, increased from $220^{\circ} \mathrm{C}$ to $280^{\circ} \mathrm{C}$ at $5^{\circ} \mathrm{C} / \mathrm{min}$, and then held for $2 \mathrm{~min}$. We injected $1.0 \mu \mathrm{L}$ of the prepared sample into the GC-MS in splitless mode with an interface temperature of $280^{\circ} \mathrm{C}$ [31].

\subsection{Data Analysis}

PAEs removal efficiencies were calculated with the following Equation (1).

$$
R_{P A E s}=\left(C_{I}-C_{E}\right) / C_{E}
$$

where: $R_{P A E S}$ was removal rates of PAEs and $C_{I}$ and $C_{E}$ represented influent and effluent concentration, respectively.

The soil-water partition coefficient $\left(K_{d}, \mathrm{~L} / \mathrm{g}\right)$ was the ratio of PAEs concentrations in soils to those in water, calculating with the following Equation (2).

$$
K_{d}=\mathrm{C}_{\mathrm{w}} / \mathrm{C}_{\mathrm{s}}
$$

where $C_{w}$ represented PAEs concentration in water and $C_{s}$ represented PAE concentration in soils.

The root-water concentration factor (RWCF, Equation (3)) and root-soil concentration factor (RSCF, Equation (4)) were calculated as the PAEs level in root to that in water and soil, respectively. The translocation factor (TF, Equation (5)) was calculated as the ratio of PAEs level in leaves to that in roots [6].

$$
\begin{gathered}
\text { RWCF }=C_{r} / C_{w} \\
\text { RSCF }=C_{r} / C_{s} \\
\text { TF }=C_{1} / C_{r}
\end{gathered}
$$

where $C_{r}$ and $C_{1}$ represented PAEs concentration in roots and leaves of Phragmites australis, respectively. $\mathrm{C}_{\mathrm{W}}$ and $\mathrm{C}_{\mathrm{S}}$ represented PAEs concentration in water and soils, respectively.

All reported data were the means of three replicates. All the experimental results were expressed on the dry weight of soil and plant tissues. Data that followed a normal distribution was subjected to analysis with one-way ANOVA and least significant differences for comparison of treatment means $(p<0.05)$. All data were processed using the SPSS software (SPSS Inc., Chicago, IL, USA, version 14.0).

\section{Results and Discussion}

\subsection{PAEs Removal in Constructed Wetland}

Figure 2A illustrated the change of PAEs concentrations in the influent. DBP was the most abundant PAEs and its concentration ranged from $0.08 \mu \mathrm{g} / \mathrm{L}$ to $0.70 \mu \mathrm{g} / \mathrm{L}$, followed by DEHP $(0.16 \mu \mathrm{g} / \mathrm{L}$ to $0.74 \mu \mathrm{g} / \mathrm{L})$, DEP $(0.03 \mu \mathrm{g} / \mathrm{L}$ to $0.26 \mu \mathrm{g} / \mathrm{L})$, and DMP $(0.03 \mu \mathrm{g} / \mathrm{L}$ to $0.16 \mu \mathrm{g} / \mathrm{L})$. Compared to the effluents of most wastewater treatment plants, the PAEs levels in the present study were relatively low. In Finland, the concentration of DEHP in wastewater effluent was $98 \mu \mathrm{g} / \mathrm{L}$ to $122 \mu \mathrm{g} / \mathrm{L}$, but less than $5 \mu \mathrm{g} / \mathrm{L}$ for other PAEs [32]. The DEHP in Marne Aval region was also the dominant PAEs in the pretreated water, and the concentrations of the four targeted PAEs were $22.46 \mu \mathrm{g} / \mathrm{L}$ (DEHP), $7.71 \mu \mathrm{g} / \mathrm{L}$ (DEP), $1.10 \mu \mathrm{g} / \mathrm{L}$ (DBP), and $0.82 \mu \mathrm{g} / \mathrm{L}$ (DMP) [13]. In the UK, the concentration of DEP $(25 \mu \mathrm{g} / \mathrm{L})$ was higher than those of DEHP $(23.6 \mu \mathrm{g} / \mathrm{L}), \mathrm{DBP}(2.54 \mu \mathrm{g} / \mathrm{L})$ and DMP $(0.26 \mu \mathrm{g} / \mathrm{L})$ in the raw sewage [33]. 


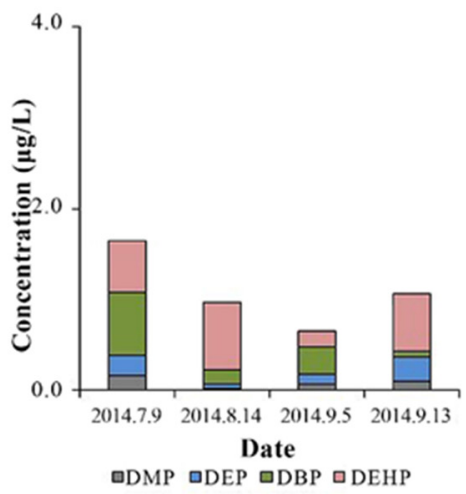

(A)

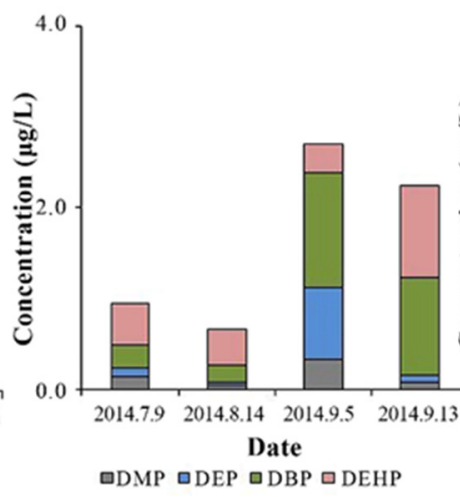

(B)

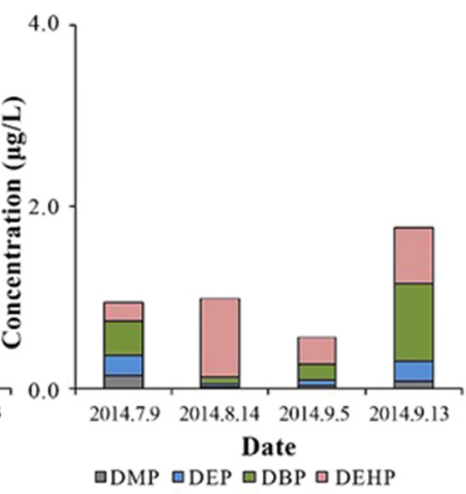

(C)

Figure 2. Phthalate acid ester (PAE) concentrations in water (A) for influent, constructed wetland with P. australis (B), and effluent (C).

The PAE moisture level inside the constructed wetland was surprisingly higher than those in the influent, as illustrated in Figure 2B. This may be due to the desorption of PAEs in soil and then combining with colloids.

In the effluent, different PAEs removal efficiencies were observed in the constructed wetland (Figure 2A,C). During the sampling period, the DMP, DEP, DBP, and DEHP were averagely removed $19.32 \%, 19.18 \%, 19.40 \%$, and $48.56 \%$, respectively. Comparing to the removal efficiency of wastewater treatment plants around the world, the constructed wetland in this study had a relatively lower PAEs removal efficiency. In French, the reduction of PAEs achieved 90\%, 90\%, 86\%, and 78\% for DMP, DEP, DBP and DEHP, table, respectively [13]. In Finland, the DEHP removal efficiency averaged 94\% [32] and in Australia, the elimination rates of DEP and DBP were $98 \%$ and $94 \%$, respectively [34]. There may be two reasons for this disparity in removal rates. Firstly, it is due to the difference processes in the two treatment systems. In wastewater treatment plants in France, Finland, and Australia, PAEs were functioned by pretreatment, suspended sediment, biological treatment, nitrification, and final effluent $[13,32,34]$. In our study, the constructed wetland showed a certain ability to remove PAEs but was less effective than the traditional wastewater treatment plants, in which the operating conditions were precisely controlled to achieve the highest removal efficiency. Secondly, PAEs concentration in the influents varied. The original concentration of DMP, DEP, DBP, and DEHP in French treatment plants were $0.82 \pm 1.13 \mathrm{ug} / \mathrm{L}, 7.71 \pm 5.21 \mathrm{ug} / \mathrm{L}, 1.10 \pm 0.37 \mathrm{ug} / \mathrm{L}, 22.46 \pm 13.22 \mathrm{ug} / \mathrm{L}$, respectively [13]. In Finland, the influent concentration of DEHP was 98-122 ug/L [32] and of DEP and DBP was $1.08 \mathrm{ug} / \mathrm{L}$ and $0.20 \mathrm{ug} / \mathrm{L}$ in Australia [34]. The unsatisfied removal rates in this study were possibly attributed to their low levels in the influent and poor uptake by plants [22].

Comparing to other constructed wetlands, the PAEs removal efficiencies in the present study were also lower. Nearly 100\% DBP elimination ratio was found in Liang's work, from $14.85 \mathrm{mg} / \mathrm{L}$ to $0.7 \mu \mathrm{g} / \mathrm{L}$, after treated by two constructed wetlands systems with vertical and reverse-vertical flows [35]. Similarly, higher DBP removal was also found in Zhao's study [36], where the average DBP concentration declined from $9.84 \mathrm{mg} / \mathrm{L}$ in influent to $5.82 \mu \mathrm{g} / \mathrm{L}$ in effluent by an integrated vertical-flow constructed wetland. However, in these systems, the influent concentrations of PAEs were much higher than the normal PAEs contamination level in the natural aqueous system around the world. In Weihe River in China, the PAEs concentrations were found at low level (DEP, not detected (ND)-4.023 $\mu \mathrm{g} / \mathrm{L}$; DBP, ND-3.168 $\mu \mathrm{g} / \mathrm{L}$; DEHP, 0.079-8.341 $\mu \mathrm{g} / \mathrm{L}$ ) [37], as well as the concentrations in other rivers in China (DBP, DEP, and DEHP were 9-61 $\mu \mathrm{g} / \mathrm{L}, \mathrm{ND}-4 \mu \mathrm{g} / \mathrm{L}$, and ND-32 $\mu \mathrm{g} / \mathrm{L}$, respectively) [38]. In some Korean rivers, DMP concentration was around $1.59 \mu \mathrm{g} / \mathrm{L}$ [4], and in French Seine Rivers, DBP $(0.047-0.14 \mu \mathrm{g} / \mathrm{L})$, DEP (ND-0.48 $\mu \mathrm{g} / \mathrm{L})$, and DEHP $(0.107-0.636 \mu \mathrm{g} / \mathrm{L})$ were found [39].

In this research, we got an order of removal by DMP $<$ DEP $<$ DBP $<$ DEHP, which is in reverse order in Tang's research, where the removal of PAEs in domestic sewage through horizontal subsurface 
flow constructed wetlands achieved $68-74 \%$ for DMP, $44-51 \%$ for DEP, $43-55 \%$ for DBP, and $21-34 \%$ for DEHP [22]. Previous research has shown that biodegradation contributed a larger part of removal efficiencies for DMP and DEP (75-99\%) than for DEHP (only 1-44\%) [33]. Moreover, studies suggest that the removal efficiency of PAEs in constructed wetlands is related to the length of the alkyl-side chains. In other words, PAEs with short ester hydrocarbon chains are more readily biodegraded and mineralized than those with long ester chains, some of which are considered recalcitrant $[40,41]$. The lower removals of DMP and DEP in this study may be due to the lower nutrients for microbiology in the influent (COD of $30-50 \mathrm{mg} / \mathrm{L}, \mathrm{NH}^{+}{ }_{4}-\mathrm{N}$ of $2-3 \mathrm{mg} / \mathrm{L}$, and $\mathrm{TP}$ of $3-5 \mathrm{mg} / \mathrm{L}$ ) and resulted in a lower strength of biodegradation on DMP and DEP.

\subsection{PAEs Absorption in Soils}

Among the four targeted PAEs (Figure 3), soils had the highest contents of DBP, which ranged from $0.36 \mu \mathrm{g} / \mathrm{g}$ to $5.09 \mu \mathrm{g} / \mathrm{g}$ (mean concentration $2.16 \pm 1.83 \mu \mathrm{g} / \mathrm{g}$ ), followed by DEHP (mean concentration $1.82 \pm 0.47 \mu \mathrm{g} / \mathrm{g})$. Soil DMP and DEP remained at relatively low levels throughout the study period, with averages of $0.29 \pm 0.12$ and $0.53 \pm 0.31 \mu \mathrm{g} / \mathrm{g}$, respectively. During the two-month operation, a significant accumulation of DEHP, DBP, and DEP was found in soils $(p<0.001)$ without DMP $(p>0.05)$. Compared to other studies, the levels and profiles of PAEs in soils were similar in the present study. In Japan, the concentrations of DEHP in the sediments of Jinzu River and Oyabe River were $0.02 \mu \mathrm{g} / \mathrm{g}$ to $0.30 \mu \mathrm{g} / \mathrm{g}$ and $0.02 \mu \mathrm{g} / \mathrm{g}$ to $1.80 \mu \mathrm{g} / \mathrm{g}$, respectively [42]. The similar PAEs concentrations were also found in some sediments in China, including of Kaohsiung Harbor (DEHP, $0.40 \mu \mathrm{g} / \mathrm{g}$ to $34.80 \mu \mathrm{g} / \mathrm{g}$; DBP, ND to $1.31 \mu \mathrm{g} / \mathrm{g}$; DMP and DEP, ND) [43], the Pearl River Delta (DEHP, $0.03 \mu \mathrm{g} / \mathrm{g}$ to $170.0 \mu \mathrm{g} / \mathrm{g}$; DBP, $0.310 \mu \mathrm{g} / \mathrm{g}$ to $2.8 \mu \mathrm{g} / \mathrm{g}$; DEP, $0.009 \mu \mathrm{g} / \mathrm{g}$ to $0.12 \mu \mathrm{g} / \mathrm{g}$; DMP, $0.003 \mu \mathrm{g} / \mathrm{g}$ to $0.20 \mu \mathrm{g} / \mathrm{g}$ ) [44], and urban lakes in Guangzhou (DEHP, $0.21 \mu \mathrm{g} / \mathrm{g}$ to $14.16 \mu \mathrm{g} / \mathrm{g}$; DBP, $0.082 \mu \mathrm{g} / \mathrm{g}$ to $1.26 \mu \mathrm{g} / \mathrm{g}$; DEP, $0.028 \mu \mathrm{g} / \mathrm{g}$ to $1.05 \mu \mathrm{g} / \mathrm{g} ; \mathrm{DMP}, 0.001 \mu \mathrm{g} / \mathrm{g}$ to $0.43 \mu \mathrm{g} / \mathrm{g}$ ) [45].

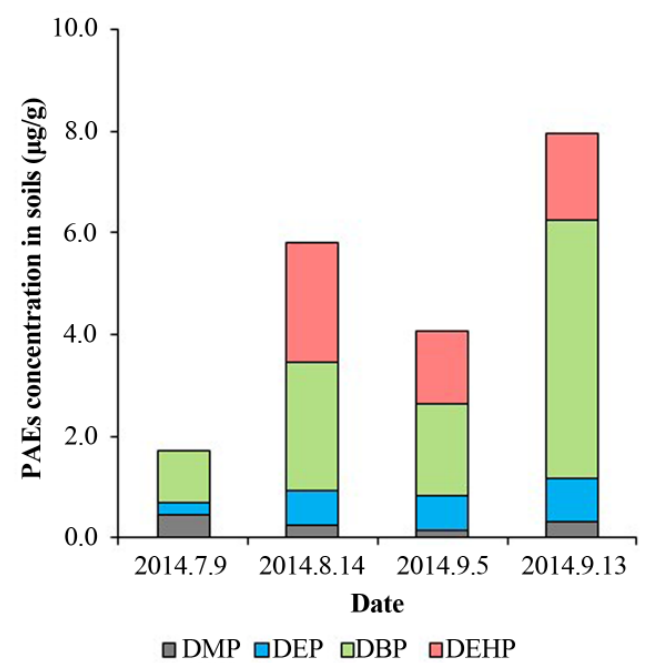

Figure 3. The relative distribution of the different PAE in soils at different sampling times.

In most of the cases, DBP and DEHP were observed as the major PAEs in soils, attributing to their high octanol/water partition coefficient $\left(K_{o w}\right)$, which represented the migration of hydrophobic organic matters (PAEs in this study) between soils and water [46]. The values of $\log K_{o w}$ are 1.60, 2.42, 4.50, and 7.60 for DMP, DEP, DBP, and DEHP, respectively [47]. Here, the soil-water partition coefficients $\left(K_{d}\right)$ were calculated and illustrated in Figure 4A. The partition of DMP, DEP, and DBP between soils and water fitted well with the trends of $\log K_{o w}$, and their increasing partition in soils was attributed to the increasing $K_{o w}$. This is agreed with the previous research as it has reported that with log $K_{o w}$ increases, there is a greater tendency for organic substances to adsorb on soil [41]. Nevertheless, the $K_{d}$ of DEHP was much lower than expected (>4) [41]. This lower $K_{d}$ of DEHP may differ due to the high 
absorption of plants for DEHP. We can know that the DEHP concentrations of treatments with plant growth were significantly lower than those without plants [48].

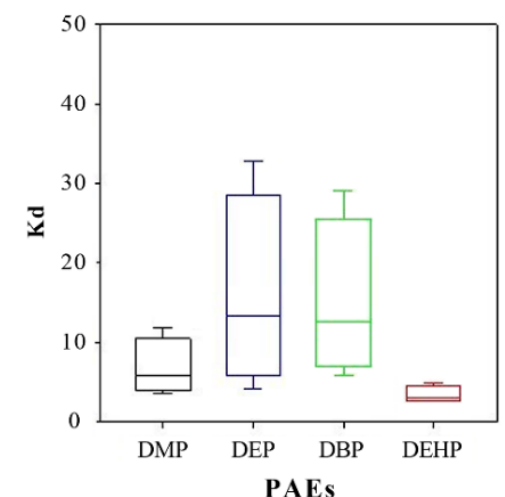

(A)

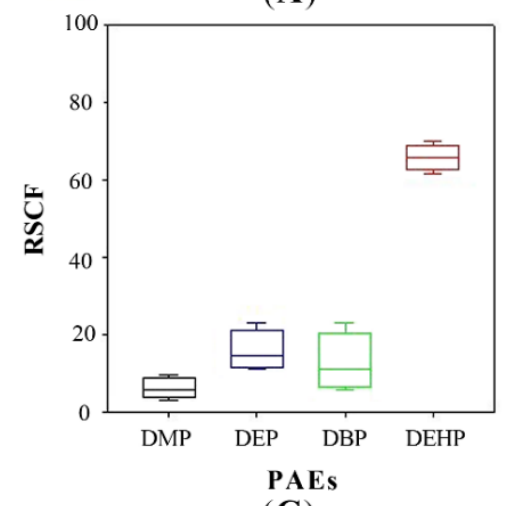

(C)

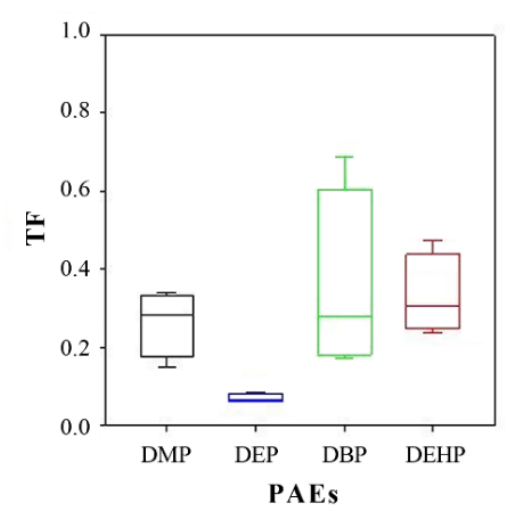

(B)

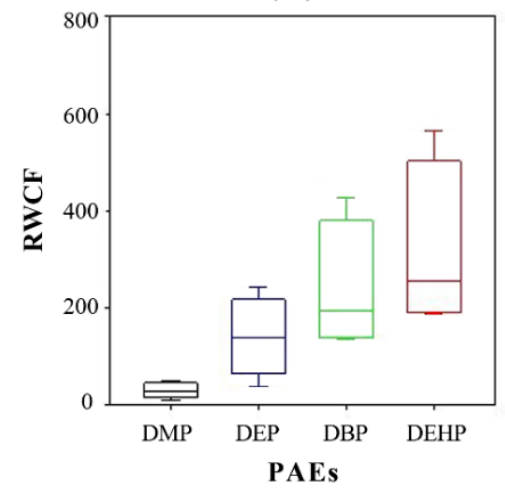

(D)

Figure 4. Key parameters of PAEs partitioning in constructed wetland. (A) Soil-water partition coefficient $\left(K_{d}\right),(\mathbf{B})$ translocation factor $(\mathrm{TF}),(\mathbf{C})$ root-soil concentration factor (RSCF), and (D) root-water concentration factor (RWCF).

\subsection{PAEs Uptake by Plants}

Of all the PAEs, DEHP had the highest concentrations in plant tissues $(26.67-177.68 \mathrm{mg} / \mathrm{kg})$, followed by DBP (10.41-48.66 mg/kg), DEP (2.25-16.97 mg/kg), and DMP (0.69-2.04 mg/kg). Moreover, it contributed to PAEs removal in wetlands. Several previous studies have reported similar plant uptake of PAEs. Yin examined the uptake of DBP and DEHP by Capsicum and found the increasing DBP concentration in plant tissues with soil DBP, whereas the uptake of DEHP was not observed [49]. In contrast, Li's work proved the uptake of DEHP by eleven plant species, including Zeamays, alfalfa, ryegrass, teosinte, etc., and the average removal rates ranged from $66.8 \%$ to $87.5 \%$ [48]. Potamogeton crispus L. can uptake and accumulate DBP and DEHP, enhancing the removal of DBP and DEHP from water by $6.3 \%$ and $22.4 \%$, compared with no plants, respectively [50]. Comparing to previous work on DEHP uptake by Zea mays spp. and Medicago sativa [48], in which the DEHP was $0.87 \mu \mathrm{g} / \mathrm{g}$ to $2.46 \mu \mathrm{g} / \mathrm{g}$ in shoots and $0.53 \mu \mathrm{g} / \mathrm{g}$ to $1.86 \mu \mathrm{g} / \mathrm{g}$ in roots, P. australis showed much stronger capacities in accumulating DEHP. These results indicated that uptake of PAEs by plants was somewhat species-specific. The differences in the plant uptake of PAEs between plant species may be attributed to differences in plant lipid contents [6].

PAEs concentrations were much higher in roots than those in stems and leaves throughout the experiment (Figure 5). This was because phthalates are hydrophobic compounds, and their sorption to plant roots is likely influenced by the lipid content [6], and roots with the higher lipid content than most other plant tissues may preferentially accumulate hydrophobic compounds [51]. Translocation factor (TF), defined as the tested PAEs concentration ratio of the shoots to the roots, was a value reflecting 
PAEs transport to aerial tissues from the roots, is used in this research. The values of TFs of DMP, DBP, and DEHP were similar as $0.264 \pm 0.059,0.355 \pm 0.166$, and $0.330 \pm 0.073$, respectively, much higher than that of DEP $(0.070 \pm 0.008)$ (Figure $4 \mathrm{~B})$. The values of TF are reported to vary among different plant species. TFs are $0.13-0.34$ for DBP and $0.73-0.88$ for DEHP in edible plants, such as lettuce and carrot [6]. The TF of DEHP is 0.627-2.31 (Zea mays spp.) and 0.835 (Medicago sativa) [48]. From the theory of transpiration stream concentration factor (TSCF), high hydrophobic organic compounds (higher $\log K_{o w}$ ) are easier to be uptaken by plants, but they also tend to be strongly adsorbed to soil organic matters, consequently resulting in low concentrations in the soil solution [52]. Thus, the bell shape of TF against $\log K_{o w}$ has been widely discussed and accepted, and the model suggests moderate hydrophobic chemicals $\left(0.5<\log K_{o w}<3\right)$ have the highest TFs. DMP and DEP are therefore expected to have the highest TF values in this study, but our results illustrated an entirely different trend that the TF value of DEP was the lowest, as illustrated in Figure 4B. This may be caused by joint action of adsorption on soils and dissolution in water. The enhanced dissipation of DEHP in the presence of vegetation might be derived from plant-promoted biodegradation and sorption stronger to the soil. Furthermore, the small number of samples may also be the cause of this result.

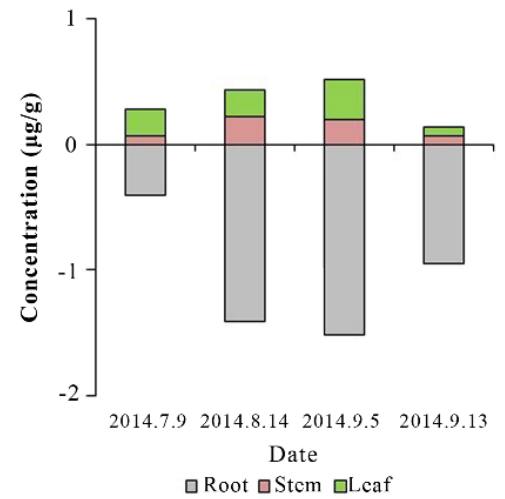

(A)

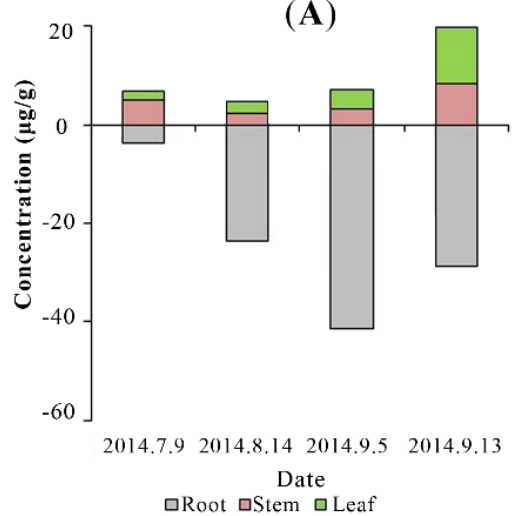

(C)

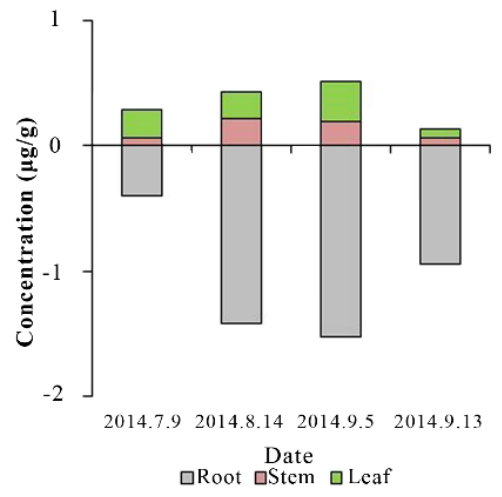

(B)

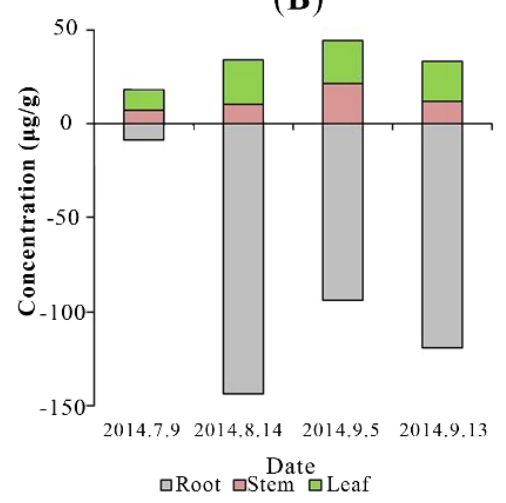

(D)

Figure 5. The concentrations of $\operatorname{DMP}(\mathbf{A}), \operatorname{DEP}(\mathbf{B}), \mathrm{DBP}(\mathbf{C})$, and DEHP (D) in the roots, stems, and leaves of $P$. australis.

The contribution of plant uptake to the total enhanced dissipation of the tested four PAEs in the present research was less than $0.20 \%$, which may be underestimated as only the unaltered PAEs were analyzed without consideration of those transformed PAEs during plant uptake. The studies on pesticides have highlighted the capacity of plant metabolism after uptake [53]. The pathways of plant uptake for lipophilic xenobiotics are phase I activation reactions and phase II conjugation reactions/synthesis [54]. During the phase I plant metabolism, which usually involves hydrolysis or oxidation, xenobiotics may undergo hydroxylation or hydrolysis [54], where reactions such as hydrolysis lead to the formation of the corresponding MPEs (monoalkyl phthalate esters) from PAEs [6]. The conjugation reactions of phase II had added functional groups like hydroxyl or carboxyl and the 
monoesters were further transformed [6,54]. Therefore, further research on PAE transformation and metabolism is needed for an accurate understanding of the plant's work on PAEs.

\subsection{PAEs Distribution and Fate}

The distribution and fate of the four targeting PAEs across multimedia in the constructed wetland are shown in Figure 6. In our research, constructed wetland digested DMP (19.32\%), DEP (19.18\%), DBP (19.40\%), and DEHP (48.56\%). The PAEs in water (blue bar) accounted for the majority of PAEs, declining with the increasing $K_{o w}$ for the adsorption by soil and plant. The DEHP with the highest $K_{o w}$ has the best adsorption effect. The adsorption by soil and plant can rise up to $50.68 \%$. Elsewhere, the adsorption ratio for DBP, DEP, and DMP, respectively, was $49.55 \%, 30.11 \%$, and $1.87 \%$. Therefore, the horizontal subsurface flow constructed wetland in this study can efficiently remove most PAEs, with the removal efficiency $20-50 \%$. The mass balance of PAEs (as shown in Figure 6C) was calculated by the influent concentration and daily treatment capacity of the constructed wetland in this work. Removal mechanisms of PAEs and the specific amount of each removal pathway are also shown.

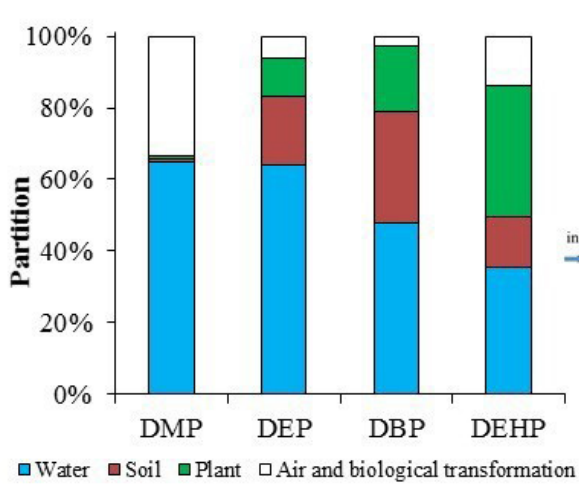

(A)

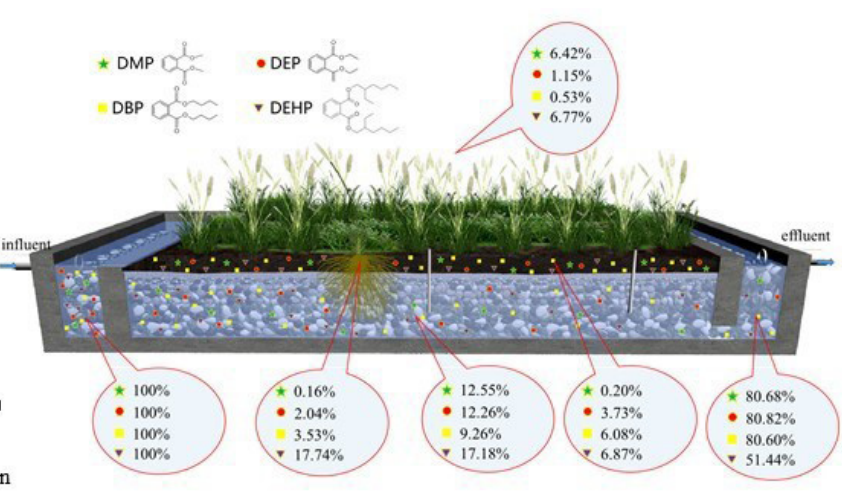

(B)

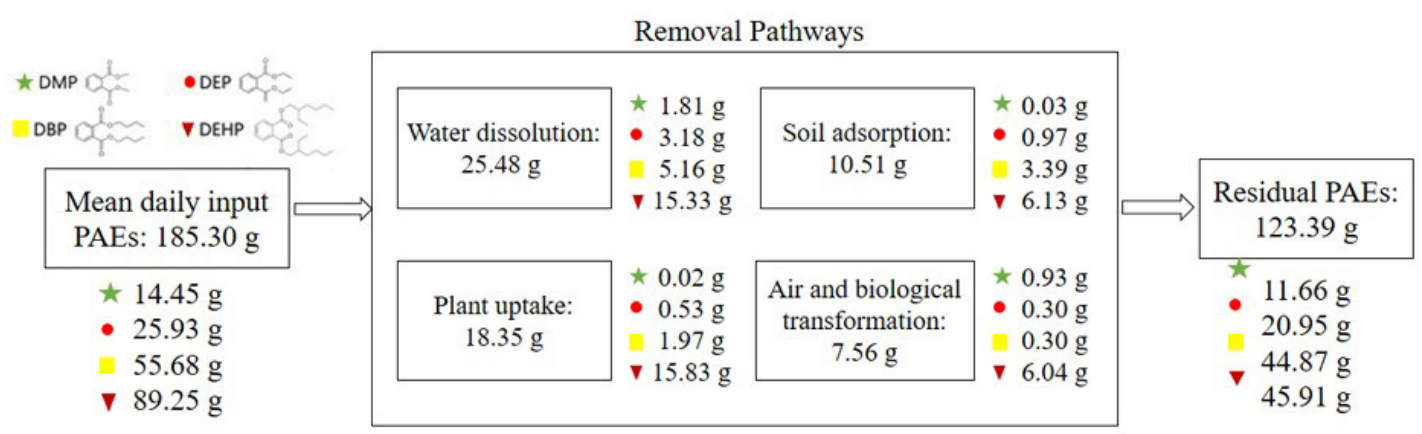

(C)

Figure 6. PAEs distribution and fate. (A) Multimedia distribution and the fate of PAEs in soil, plant, air, and water of the constructed wetland. (B) Fate of PAEs in the system of constructed wetland. (C) Mass balance calculation of PAEs in all pathways.

However, the adsorptive behaviors of soil and plant were not identical. The fraction of soil adsorption (brown bar) was positively correlated with $K_{d}$ values of PAEs. DEP and DBP have the highest $K_{d}$, and their proportion in soils was $19.44 \%$ and $31.33 \%$, respectively. The corresponding removal pathway in mass balance calculation is soil adsorption in Figure 6C. The highest plant partition was found for DEHP (36.54\%), followed by DBP (18.22\%), DEP $(10.66 \%)$, and DMP $(0.85 \%)$. The corresponding removal pathway is plant uptake in mass balance calculation. The partition of PAEs in the plant (green bar) had a positive relationship with the RSCF and RWCF. As for the rest of PAEs, they might be evaporated as or degraded by biochemical processes in the wetland. And highest 
air and biological transformation were found for DMP (33.21\%), followed by DEHP (13.94\%), DEP $(5.97 \%)$, and DBP $(2.72 \%)$.

Typically, the translocation of high hydrophobic contaminants from soil to the shoot tissues is small [55]. As several literature reviews have shown, the plant uptake of DEHP with lower water solubility (about $0.40 \mathrm{mgL}^{-1}$ ) and higher $\log K_{o w}$ (7.0-7.8 range) was small [22]. The difference between the relationship between a plant's uptaking capacity and $\log K_{o w}$ obtained in this study and those previously reported is not clear but could be caused by a variety of factors including plant growth conditions, plant species, plant age, duration, transpiration, and losses due to metabolism and volatilization. Restrainedly, we believe that rather low concentrations of nutrients presented as COD, ammonia, and total phosphorus in the tested influent reduced the microbial mass than the biodegradation of PAEs. Moreover, the low level of PAEs in the influent decreased the driving force for bioreaction, including micro-biodegradation and plant uptake. That is, PAEs may take different paths in lightly polluted water and heavily polluted water. Compared with the previous study [22], it seems that adsorption contributes the most removal for lightly polluted water and bioreaction for that of heavily polluted water. This agrees with the research of Tang considering the PAEs with short ester hydrocarbon chains being more readily biodegraded and mineralized than those with long ester chains [22]. Tang reported a strong correlation between removal efficiencies and key nutrients (DO and COD) for microbiological mass for PAEs with short ester hydrocarbon chains (DMP and DEP), while a relatively weak correlation of that for PAEs with long ester hydrocarbon chains (DBP and DEHP) [22]. Details on microhabitat are needed for further insight.

\section{Conclusions}

In this study, a full-scale horizontal subsurface flow constructed wetland was investigated for its satisfactory performance in reducing PAEs, as well as the partition and fate of PAEs throughout the system. Results show that (1) the removal efficiency varied among DMP, DEP, DBP, and DEHP, attributing to their different $K_{o w}$ and partition across the multimedia; (2) $K_{o w}$ increased from DMP to DEP and DBP, contributing to the increasing adsorption in soils and uptake by P. australis; (3) DEHP had the highest $K_{o w}$ among the four PAEs with the lowest soil adsorption and the highest plant uptake, indicating an intense adsorption competition between plant and soils.

Our research revealed that $K_{o w}$ is a crucial factor affecting PAEs partition in constructed wetlands. Further study will be required to identify ways to enhance the PAEs removal efficiency. For example, soils with a different textural class or mineral composition and a mixture of plant species may improve the removal efficiency. Moreover, it will be necessary to quantify the removal of PAEs by chemical reactions in the soil or water and by microbes, since both are potentially essential processes.

Author Contributions: L.Z.: Conceptualization, Methodology. T.L., E.X., M.L., A.D., and B.-T.Z.: Formal analysis. T.L. and M.L.: Writing-Original draft preparation. L.Z. and T.L.: Writing Reviewing and Editing. L.Z. and E.X.: Funding acquisition. X.L. and D.Z.: data analysis and discussion. All authors have read and agreed to the published version of the manuscript.

Acknowledgments: This research was supported by the Natural Science Foundation of Beijing (Z170004), National Natural Science Foundation of China (No. 51509003) and the Beijing Municipal Science and Technology Commission (D161100000216001). We appreciate the help of Bruce Anderson, Shubiao Wu and Goffery Hart for their valuable editing language.

Conflicts of Interest: The authors declare no conflict of interest.

\section{References}

1. Gao, D.; Li, Z.; Wen, Z.; Ren, N. Occurrence and fate of phthalate esters in full-scale domestic wastewater treatment plants and their impact on receiving waters along the Songhua River in China. Chemosphere 2014, 95, 24-32. [CrossRef]

2. Koniecki, D.; Wang, R.; Moody, R.P.; Zhu, J. Phthalates in cosmetic and personal care products: Concentrations and possible dermal exposure. Environ. Res. 2011, 111, 329-336. [CrossRef] [PubMed] 
3. Okamoto, Y.; Ueda, K.; Kojima, N. Potential risks of phthalate esters: Acquisition of endocrine-disrupting activity during environmental and metabolic processing. J. Health Sci. 2011, 57, 497-503. [CrossRef]

4. Cho, E.; Khim, J.; Chung, S.; Seo, D.; Son, Y. Occurrence of micropollutants in four major rivers in Korea. Sci. Total Environ. 2014, 491-492, 138-147. [CrossRef] [PubMed]

5. Liu, H.; Cui, K.; Zeng, F.; Chen, L.; Cheng, Y.; Li, H.; Li, S.; Zhou, X.; Zhu, F.; Ouyang, G.; et al. Occurrence and distribution of phthalate esters in riverine sediments from the Pearl River Delta region, South China. Mar. Pollut. Bull. 2014, 83, 358-365. [CrossRef] [PubMed]

6. Sun, J.; Wu, X.; Gan, J. Uptake and metabolism of phthalate esters by edible plants. Environ. Sci. Technol. 2015, 49, 8471-8478. [CrossRef] [PubMed]

7. Bergé, A.; Gasperi, J.; Rocher, V.; Gras, L.; Coursimault, A.; Moilleron, R. Phthalates and alkylphenols in industrial and domestic effluents: Case of Paris conurbation (France). Sci. Total Environ. 2014, 488-489, $26-35$. [CrossRef] [PubMed]

8. Kang, Y.; Man, Y.; Cheung, K.; Wong, M. Risk assessment of human exposure to bioaccessible phthalate esters via indoor dust around the Pearl River Delta. Environ. Sci. Technol. 2012, 46, 8422-8430. [CrossRef]

9. Joel, D.B. Ultra-trace determination of phthalate ester metabolites in seawater, sediments, and biota from an urbanized marine inlet by LC/ESI-MS/MS. Environ. Sci. Technol. 2009, 16, 6262-6268.

10. Hanno, C.E. Leaching of the plasticizer di(2-ethylhexyl)phthalate (DEHP) from plastic containers and the question of human exposure. Appl. Microbiol. Biot. 2014, 24, 9967-9981.

11. He, W.; Qin, N.; Kong, X.; Liu, W.; He, Q.; Ouyang, H.; Yang, C.; Jiang, Y.; Wang, Q.; Yang, B.; et al. Spatio-temporal distributions and the ecological and health risks of phthalate esters (PAEs) in the surface water of a large, shallow Chinese lake. Sci. Total Environ. 2013, 461-462, 672-680. [CrossRef] [PubMed]

12. Ventrice, P.; Ventrice, D.; Russo, E.; Sarro, G. Phthalates: European regulation, chemistry, pharmacokinetic and related toxicity. Environ. Toxicol. Phar. 2013, 36, 88-96. [CrossRef] [PubMed]

13. Dargnat, C.; Teil, M.-J.; Chevreuil, M.; Blanchard, M. Phthalate removal throughout wastewater treatment plant: Case study of Marne Aval station (France). Sci. Total Environ. 2009, 407, 1235-1244. [CrossRef]

14. Adhoum, N.; Monser, L. Removal of phthalate on modified activated carbon: Application to the treatment of industrial wastewater. Sep. Purif. Technol. 2004, 38, 233-239. [CrossRef]

15. Gültekin, I.; Ince, N.H. Synthetic endocrine disruptors in the environment and water remediation by advanced oxidation processes. J. Environ. Manage. 2007, 85, 816-832. [CrossRef] [PubMed]

16. Zolfaghari, M.; Drogui, P.; Seyhi, B.; Brar, K.; Buelna, G.; Dubé, R. Occurrence, fate and effects of di (2-ethylhexyl) phthalate in wastewater treatment plants: A review. Environ. Pollut. 2014, 194, 281-293. [CrossRef] [PubMed]

17. Kivaisi, A.K. The potential for constructed wetlands for wastewater treatment and reuse in developing countries: A review. Ecol. Eng. 2001, 16, 545-560. [CrossRef]

18. Ye, J.; Xu, Z.X.; Li, H.Z. Dynamic rule of organic matter removal in vertical-flow constructed wetland. Environ. Sci. 2008, 29, 2166-2171.

19. Gruchlik, Y.; Linge, K.; Joll, C. Removal of organic micropollutants in waste stabilisation ponds: A review. J. Environ. Manage. 2018, 206, 202-214. [CrossRef]

20. Zhu, S.; Chen, H. The fate and risk of selected pharmaceutical and personal care products in wastewater treatment plants and a pilot-scale multistage constructed wetland system. Environ. Sci. Pollut. R. 2014, 21, 1466-1479. [CrossRef]

21. Stales, C.A.; Peterson, D.R.; Parkerton, T.; Adams, W. The environmental fate of phthalate esters: A literature review. Chemosphere 1997, 35, 667-749. [CrossRef]

22. Tang, X.; Suyu, W.; Yang, Y.; Ran, T.; Dai, Y.-N.; Dan, A.; Li, L. Removal of six phthalic acid esters (PAEs) from domestic sewage by constructed wetlands. Chem. Eng. J. 2015, 275, 198-205.

23. Wania, F.; Mackay, D. A global distribution model for persistent organic chemicals. Sci. Total. Environ. 1995, 160-161, 0-232. [CrossRef]

24. Xu, F.L.; Qin, N.; Zhu, Y.; He, W.; Kong, X.Z.; Barbour, M.; He, Q.S.; Wang, Y.; Ouyang, H.; Tao, S. Multimedia fate modeling of polycyclic aromatic hydrocarbons (PAHs) in Lake Small Baiyangdian, Northern China. Ecol. Model. 2013, 252, 246-257. [CrossRef]

25. Wania, F.; Dugani, S. Assessing the long-range transport potential of polybrominated diphenyl ethers: A comparison of four multimedia models. Environ. Toxicol. Chem. 2003, 22, 1252-1261. [CrossRef] 
26. Zhu, Y.; Tao, S.; Price, O.; Shen, H.; Jones, K.; Sweetman, A. Environmental distributions of benzo[a]pyrene in China: Current and future emission reduction scenarios explored using a spatially explicit multimedia fate model. Environ. Sci. Technol. 2015, 49, 13868-13877. [CrossRef] [PubMed]

27. Zhu, Y.; Price, O.; Tao, S.; Jones, K.; Sweetman, A. A new multimedia contaminant fate model for China: How important are environmental parameters in influencing chemical persistence and long-range transport potential? Environ. Int. 2014, 6, 18-27. [CrossRef]

28. Hsu, F.C.; Marxmiller, R.L.; Yang, A.Y. Study of root uptake and xylem translocation of cinmethylin and related compounds in detopped soybean roots using a pressure chamber technique. Plant. Physiol. 1990, 93, 1573-1578. [CrossRef]

29. Tian, F.; Liu, Y.; Liu, C.; Gu, H.; Liu, H. Pollution Status and multimedia fate simulation of phthalate acid esters (PAEs) in an arid city. Pol. J. Environ. Stud. 2016, 25, 325-331.

30. Simon, S.; Graham, J.C.; Terp, S.D. Uptake of 40K and 137Cs in native plants of the Marshall Islands. J. Environ. Radioactiv. 2002, 59, 223-243. [CrossRef]

31. Zheng, X.; Zhang, B.T.; Teng, Y. Distribution of phthalate acid esters in lakes of Beijing and its relationship with anthropogenic activities. Sci. Total Environ. 2014, 476, 107-113. [CrossRef]

32. Marttinen, S.; Kettunen, R.H.; Sormunen, K.; Rintala, J. Removal of bis (2-ethylhexyl) phthalate at a sewage treatment plant. Water. Res. 2003, 37, 1385-1393. [CrossRef]

33. Oliver, R.; May, E.; Williams, J. The occurrence and removal of phthalates in a trickle filter STW. Water Res. 2005, 39, 4436-4444. [CrossRef] [PubMed]

34. Tan, B.L.; Hawker, D.W.; Mueller, J.F.; Leusch, F.D.; Tremblay, L.A.; Chapman, H.F. Modelling of the fate of selected endocrine disruptors in a municipal wastewater treatment plant in South East Queensland, Australia. Chemosphere 2007, 69, 644-654. [CrossRef] [PubMed]

35. Liang, W.; Deng, J.-q.; Zhan, F.C.; Wu, Z.B. Effects of constructed wetland system on the removal of dibutyl phthalate (DBP). Microbiol. Res. 2009, 164, 206-211. [CrossRef]

36. Yu Zhao, W.; Bin Wu, Z.; Hong Zhou, Q.; Ping Cheng, S.; Ping Fu, G.; He, F. Removal of dibutyl phthalate by a staged, vertical-flow constructed wetland. Wetlands 2004, 24, 202. [CrossRef]

37. Guo, X.; Wang, L.; Wang, X.; Liu, H. Occurrence and environmental risk assessment of PAEs in Weihe River near Xi'an City, China. Water Sci. Technol. 2013, 67, 948-958. [CrossRef]

38. Wu, X.; Hong, H.; Liu, X.; Guan, W.; Meng, L.; Ye, Y.; Ma, Y. Graphene-dispersive solid-phase extraction of phthalate acid esters from environmental water. Sci. Total Environ. 2013, 444, 224-230. [CrossRef]

39. Teil, M.-J.; Blanchard, M.; Moreau-Guigon, E.; Dargnat, C.; Alliot, F.; Bourges, C.; Desportes, A.; Chevreuil, M. Phthalate fate in the hydrographic network of the river Seine basin (France) under contrasted hydrological conditions. Water Air Soil Poll. 2013, 224, 1592-1606. [CrossRef]

40. Liang, D.-W.; Zhang, T.; Fang, H.; He, J. Phthalates biodegradation in the environment. Appl. Microbiol. Biot. 2008, 80, 183. [CrossRef]

41. Julinová, M.; Slavík, R. Removal of phthalates from aqueous solution by different adsorbents: A short review. J. Environ. Manage. 2012, 94, 13-24. [CrossRef] [PubMed]

42. Yuwatini, E.; Hata, N.; Kuramitz, H.; Taguchi, S. Effect of salting-out on distribution behavior of di (2-ethylhexyl) phthalate and its analogues between water and sediment. SpringerPlus 2013, 2, 422. [CrossRef] [PubMed]

43. Chen, C.-W.; Chen, C.-F.; Dong, C.-D. Distribution of phthalate esters in sediments of Kaohsiung Harbor, Taiwan. Soil Sediment. Contam 2013, 22, 119-131. [CrossRef]

44. Sun, H.; An, T.; Li, G.; Qiao, M.; Wei, D. Distribution, possible sources, and health risk assessment of SVOC pollution in small streams in Pearl River Delta, China. Environ. Sci. Pollut. Res. 2014, 21, 10083-10095. [CrossRef]

45. Zeng, F.; Cui, K.; Xie, Z.; Liu, M.; Li, Y.; Lin, Y.; Zeng, Z.; Li, F. Occurrence of phthalate esters in water and sediment of urban lakes in a subtropical city, Guangzhou, South China. Environ. Int. 2008, 34, 372-380. [CrossRef]

46. Sangster, J. Octanol-water partition coefficients of simple organic compounds. J. Phys. Chem. Ref. Data 1989, 18, 1111-1229. [CrossRef]

47. Jackson Ellington, J. Octanol/water partition coefficients and water solubilities of phthalate esters. J. Chem. Eng. Data 1999, 44, 1414-1418. [CrossRef] 
48. Li, Y.-W.; Cai, Q.-Y.; Mo, C.-H.; Zeng, Q.-Y.; Lü, H.; Li, Q.-S.; Xu, G.-S. Plant uptake and enhanced dissipation of di(2-Ethylhexyl) phthalate (DEHP) in spiked soils by different plant species. Int. J. Phytoremediat. 2014, 16, 609-620. [CrossRef]

49. Yin, R.; Lin, X.G.; Wang, S.G.; Zhang, H.Y. Effect of DBP/DEHP in vegetable planted soil on the quality of capsicum fruit. Chemosphere 2003, 50, 801-805. [CrossRef]

50. Chi, J.; Gao, J. Effects of Potamogeton crispus L.-bacteria interactions on the removal of phthalate acid esters from surface water. Chemosphere 2015, 119, 59-64. [CrossRef]

51. Dodgen, L.K.; Li, J.; Parker, D.; Gan, J.J. Uptake and accumulation of four PPCP/EDCs in two leafy vegetables. Environ. Pollut. 2013, 182, 150-156. [CrossRef] [PubMed]

52. Namiki, S.; Otani, T.; Seike, N. Fate and plant uptake of persistent organic pollutants in soil. Soil. Sci. Plant. Nut. 2013, 59, 669-679. [CrossRef]

53. Macherius, A.; Eggen, T.; Lorenz, W.; Moeder, M.; Ondruschka, J.; Reemtsma, T. Metabolization of the bacteriostatic agent triclosan in edible plants and its consequences for plant uptake assessment. Environ. Sci. Technol. 2012, 46, 10797-10804. [CrossRef] [PubMed]

54. Coleman, J.; Blake-Kalff, M.; Davies, E. Detoxification of xenobiotics by plants: Chemical modification and vacuolar compartmentation. Trends Plant. Sci. 1997, 2, 144-151. [CrossRef]

55. Mikeš, O.; Cupr, P.; Trapp, S.; Klanova, J. Uptake of polychlorinated biphenyls and organochlorine pesticides from soil and air into radishes (Raphanus sativus). Environ. Pollut. 2009, 157, 488-496. [CrossRef]

(C) 2020 by the authors. Licensee MDPI, Basel, Switzerland. This article is an open access article distributed under the terms and conditions of the Creative Commons Attribution (CC BY) license (http://creativecommons.org/licenses/by/4.0/). 